British Journal of Nutrition (2022), 127, 1190-1197

doi:10.1017/S0007114521001938

(C) The Author(s), 2021. Published by Cambridge University Press on behalf of The Nutrition Society. This is an Open Access article, distributed under the terms of the Creative Commons Attribution-NonCommercial-ShareAlike licence (http://creativecommons.org/licenses/by-nc-sa/4.0/), which permits non-commercial re-use, distribution, and reproduction in any medium, provided the same Creative Commons licence is included and the original work is properly cited. The written permission of Cambridge University Press must be obtained for commercial re-use.

\title{
lodine nutrition among the adult population of the Faroe Islands: a population-based study
}

\author{
Herborg Líggjasardóttir Johannesen ${ }^{1,2 *}$, Gunnar Sjúrðarson Knudsen³ ${ }^{3}$, Stig Andersen ${ }^{4,5,6}$, Pál Weihe ${ }^{2,7,8}$ and \\ Anna Sofía Veyhe $e^{2,7,8}$ \\ ${ }^{1}$ Department of Endocrinology and Medicine, The National Hospital of the Faroe Islands, Tórshavn, Faroe Islands \\ ${ }^{2}$ Center of Health Science, University of the Faroe Islands, Tórshavn, Faroe Islands \\ ${ }^{3}$ Faculty of Science and Technology, University of the Faroe Islands, Tórshavn, Faroe Islands \\ ${ }^{4}$ Department of Clinical Medicine, Aalborg University, Aalborg, Denmark \\ ${ }^{5}$ Arctic Health Research Centre, Aalborg University Hospital, Aalborg, Denmark \\ ${ }^{6}$ Greenland Centre for Health Research, University of Greenland, Nuuk, Greenland \\ ${ }^{7}$ Deparment of Occupational Medicine and Public Health, The Faroese Hospital System, Tórshavn, Faroe Islands \\ ${ }^{8}$ Faculty of Health Science, University of the Faroe Islands, Tórshavn, Faroe Islands
}

(Submitted 18 January 2021 - Final revision received 25 May 2021 - Accepted 1 June 2021 - First published online 4 June 2021)

\section{Abstract}

The WHO recommends monitoring iodine status in all populations with median urinary iodine concentration (UIC) below $100 \mu \mathrm{g} / \mathrm{l}$ suggesting iodine deficiency. There are no data on the iodine intake among the population of the Faroe Islands. This study aimed to provide data on iodine nutrition in a representative sample of the general adult population from the Faroe Islands. We conducted a population-based cross-sectional survey in 2011-2012 and measured iodine in urine from 491 participants (294/197 men/women) using the ceri/arsen method after alkaline ashing. Participants include about 100 subjects in each of four adult decades and included participants from both the capital city and villages. The median UIC was low within the recommended range $101 \mu \mathrm{g} / \mathrm{l}$ (range $21-1870 \mu \mathrm{g} / \mathrm{l})$. No samples were in the range suggesting severe iodine deficiency, but half of the samples were in the range of just adequate or mildly insufficient iodine intake with UIC markedly lower in women than in men $(86 v .115 \mu \mathrm{g} / \mathrm{l} ; P<0 \cdot 001)$. Intake of fish and whale meals affected the UIC. In conclusion, nearly half of the population had an iodine excretion in the range of borderline or mild iodine deficiency. The lowest iodine nutrition level among Faroese women is a concern as it may extend to pregnancy with increased demands on iodine nutrition. In addition, we found that large variations and the intermittently excessive iodine intakes warrant follow-up on thyroid function in the population of the Faroe Islands.

Key words: Iodine status: Urinary iodine excretion: Population-based study: Health survey: Faroe Islands: Artic society

Iodine is an essential nutrient needed to produce thyroid hormones thyroxine (T4) and triiodothyronine (T3), and the intake of iodine is a key determinant of thyroid disease risk with both low and high intakes increasing the risk of disease ${ }^{(1,2)}$. Thyroid hormones are essential for growth, neuronal development, reproduction and regulation of energy metabolism ${ }^{(3,4)}$. Mild and moderate iodine deficiency presents primarily as non-toxic goitre, an enlarged thyroid gland with normal production of thyroid hormones, and prolonged iodine deficiency may lead to hyperthyroidism and shorter lifespan ${ }^{(5)}$. Furthermore, severe iodine deficiency may lead to hypothyroidism in adults and to cretinism in infants and children ${ }^{(1,6)}$ with iodine deficiency being the single most important, preventable cause of developmental brain damage worldwide ${ }^{(7,8)}$. Thus, the WHO recommends monitoring of all populations.

More than seventy countries have introduced iodisation programmes to combat iodine deficiency disorders ${ }^{(8)}$. Denmark was mild to moderately iodine deficient and introduced iodine fortification of salt about year $2000^{(9)}$ aiming to raise the iodine intake by about $50 \mu \mathrm{g} / \mathrm{d}^{(10)}$. Follow-up has documented a marked reduction in the occurrence of goitre and thyroid dysfunctions ${ }^{(11,12)}$, while iodine nutrition in pregnant women remains a continuous concern ${ }^{(13-15)}$.

The Faroe Islands are included in the Danish iodine fortification programme similar to Greenland ${ }^{(16)}$ on a voluntary basis with non-iodised salt also available. However, no studies have

Abbreviation: UIC, urinary iodine concentration.

* Corresponding author: Herborg Líggjasardóttir Johannesen, email herjh@ls.fo 
been conducted on iodine status in the Faroese population Nevertheless, several studies conducted in the Faroe Islands on contaminant exposure ${ }^{(17)}$ included dietary and urinary sampling, which may provide insight into iodine nutrition.

We thus aimed to settle the iodine nutrition status among adult Faroese aged 40 through 74 years by measuring iodine in spot urine samples to estimate the prevalence of iodine deficiency. In addition, we included an assessment of the importance of dietary peculiarities among the Faroese for iodine nutrition in order to guide dietary recommendations in the Faroe Islands. The iodine content of water varies considerably with geography but remains stable with time, and data for the Faroe Islands are included ${ }^{(18)}$

\section{Experimental methods}

\section{Area of investigation}

The Faroe Islands, an archipelago located in the North Atlantic Ocean, are inhabited by close to 53000 individuals ${ }^{(19)}$. The islands are a part of the Nordic countries with similarities in terms of language, welfare system and lifestyle, including dietary intake. The food sources available in grocery stores in the Faroe Islands are like the sources available in grocery stores in the other Nordic countries. Dairy products in terms of milk and sour-milk products are produced locally and sold in all grocery stores, whereas the vast majority of cheeses are imported. Additionally, the Faroese cuisine includes local traditional foods like fermented and wind-dried lamb meat and fish, which has been cherished for centuries and still is ${ }^{(20)}$. Pilot whale (Globicephala melas) hunting is an old tradition too as is driving and communal sharing methods ${ }^{(21)}$. In the Faroe Islands, there are two dietary recommendations for pilot whale meat and blubber intake. One published in 2008 by the Chief Medical Officer and the Department of Occupational Medicine and Public Health stating that pilot whale is considered unsuited for human consumption due to high concentrations of environmental pollutants ${ }^{(22)}$ and the other published in 2011 by the Faroese Food and Veterinary Authority ${ }^{(23)}$ stating that a maximum of one meal per month for the adult population, but that fertile women abstain from whale blubber until last child is born and whale meat from 3 months prior to conception and during lactation period. Fish intake has declined from three meals per week in the 1930s to one meal per week among the younger generations during the 2010s, and there are indications that dairy intake had decreased markedly, from $390 \mathrm{~g} / \mathrm{d}$ in 1982 to $179 \mathrm{~g} / \mathrm{d}$ in 2016 (24).

Both iodised salt and non-fortified salt are available in all grocery stores, and although not mandatory, most of the commercial bread production in the Faroe Islands, but not all, uses iodised salt.

\section{Participants and diet questionnaire}

The study population was derived from a national crosssectional population-based survey, conducted in 2011-2012 by Department of Occupational Medicine and Public Health to investigate a possible association between environmental contamination and risk of type 2 diabetes mellitus. A total of 2186 age- and sex-adjusted individuals aged $40-74$ years were randomly selected from the Faroese Population Registry (comprising $10 \%$ of the total population in each age group). The reason for including people from the age of 40 years in the original study was that the risk for type 2 diabetes increases with age and the prevalence is low before the age of 40 years. A detailed description has been published previously ${ }^{(25)}$. At study entrance, 491 participants answered a questionnaire that pertained to personal information: schooling and education, health status and smoking habits. The questionnaire included two short sections on dietary habits. The first section posed the question: 'How often do You consume': potatoes; grains and cereals; cooked, fried or baked vegetables; salad and raw vegetables; fruit; fish as small meal or as bread-spread with six possible options from never/rarely to every day/several times per day. The second section posed the question 'How often during the last year have you consumed': fish; sea birds; pilot whale meat; pilot whale blubber with the frequency option: never; times per year; times per month; times per week. Anthropometric measures included body weight, body height, hip and waist circumference. BMI was calculated as weight in $\mathrm{kg}$ divided by height in metres squared.

\section{Ethical approval}

The study was approved by the local ethical review committee and the Data Protection Authority of the Faroe Islands, with participation on a voluntary basis as documented by written informed consent complying with the Declaration of Helsinki. Procedures done caused no harm to the participants. All data were pseudo-anonymised, and all analyses were conducted in accordance with the ethical approval.

\section{Urine and tap water sampling}

The participants ( $n$ 491) donated a morning spot urine sample at study entrance. All samples were stored in iodine-free containers at $-80^{\circ} \mathrm{C}$ at the Department of Occupational Medicine and Public Health, Torshavn, the Faroe Islands until further analyses. Tap water samples were collected at twelve locations covering the geography of the Faroe Islands for measurement of iodine in drinking water to evaluate a possible contribution to the iodine intake.

\section{Analytical methods}

We used single random sampling for measuring urinary iodine concentration (UIC) to comply with the recommendations from the international organisations WHO and UNICEF to use single random sampling UIC to compare public health data among countries. UIC portrays dietary iodine intake because more than $90 \%$ of dietary iodine is excreted in the urine and the vast majority within $24 \mathrm{~h}^{(26)}$.

The iodine concentration in water and urine was determined by the Sandell-Kolthoff reaction modified after Wilson and van $\mathrm{Zyl}^{(27)}$. The principle is detection of the catalytic role of iodine in the reduction of ceric ammonium sulphate in the presence of arsenous acid after pre-treatment with alkaline ashing ${ }^{(28)}$. Procedures were conducted at the iodine laboratory at Aalborg University Hospital (Aalborg Denmark) ${ }^{(29)}$. Samples were analysed in random order, and repeated analyses of stored batches provided quality control. 


\section{Statistical analyses and justification of sample size}

Statistical analyses were performed in Statistical Program for Social Science (version 25.0; SPSS Inc.). Continuous variables were analysed for normal distribution by visual inspection of QQ-plots and by Kolmogorov-Smirnov test. Four urine samples had UIC $>1000 \mathrm{mcg} / \mathrm{l}$, but they did not influence the statistical significances in the results and all samples were included in the further analyses. Descriptive statistics are presented with mean and standard deviation or median and interquartile range for continuous variables and numbers and percentages for categorical variables. Intake of local traditional foods, whale meat, whale blubber and fish was quantified to times intake per year, and correlations were explored with iodine status using the Spearman's rho for preliminary analyses (data not shown). Whole grain (bread and groats) was initially recorded with six categories from daily intake to never and after that converted to a binary variable: intake daily and more or less frequent than daily intake. Neither the iodine concentration nor the dietary variables were normally distributed, and groups were compared using the non-parametric Mann-Whitney $U$ test (two groups) or Kruskal-Wallis test (several groups). The $\chi^{2}$ test was applied for categorical variables. Univariate binary logistic regression was applied to further explore the link between the median iodine status $(<101 \mu \mathrm{g} / \mathrm{l} v . \geq 101 \mu \mathrm{g} / \mathrm{l})$ and the following predictor variables: sex; age; place of living (city/town); BMI groups $(<24 \cdot 9,25 \cdot 0-29 \cdot 9, \geq 30 \cdot 0)$; smoking (daily, occasionally, never) and educational level (up to 7 years, 8-11 years, upper secondary). All significant variables from the univariable logistic regression analyses were included in a multivariable binary logistic regression model using conditional backward elimination. Reported $P$-values were judged based on a statistical significance limit of 0.05 .

When settling sample size, we aimed for a $5 \%$ precision range with $95 \%$ confidence in a population. The recommended number of urine samples adds up to a total of 489 in a population ${ }^{(30)}$. This allows for three to four subgroups with a precision range of $10 \%$ with $95 \%$ confidence, and five to six subgroups with $10 \%$ precision with $90 \%$ confidence $^{(30)}$.

\section{Results}

\section{Study population characteristics}

The study group comprised 294 men and 197 women with a mean age of 59.5 (SD 9.3) and 60.4 (SD 8.8) years, respectively. Mean BMI for the whole group was $29 \cdot 7$ (SD 5.0), and a total of $86 \%$ were classified to be overweight (BMI $>25 \mathrm{~kg} / \mathrm{m}^{2}$ ) or obese $\left(\mathrm{BMI}>30 \mathrm{~kg} / \mathrm{m}^{2}\right)$ with significantly more men than women being overweight $(P<0.05)$ and obese $(P<0.05)$. More women smoked $(P<0.05)$, and $70 \%$ were non-smokers.

Men reported a more frequent intake of the whale meat and whale blubber compared with women, $6 v .3$ times per year $(P<0.001)$ and $12 v .4$ times per year $(P<0.001)$, respectively, and $44 \%$ of the women reported a daily intake of whole grain compared with $35 \%$ of the men $(P=0.04)$. Fish intake was similar between the sexes with a frequency of 104 times per year for both men and women. There were no differences between the groups regarding food items: whale meat, whale blubber, fish and whole grain. There was a weak non-significant positive correlation between fish and whale meat intake, assessed as times per year, both overall (Spearman's $P=0 \cdot 07 ; P=0 \cdot 15$ ) and stratified by sex: men, Spearman's $P=0.08 ; P=0 \cdot 18$; women, Spearman's $P=0.04 ; P=0.55$. Fish and whale blubber intake were overall positively associated, Spearman's $P=0 \cdot 12$; $P=0 \cdot 01$, but not when stratified by sex. Groups did not differ by educational level, place of living and smoking habits.

A total of eight participants were on thyroid supplementation medication, their UIC were in the range 50-99 $\mu \mathrm{g} / \mathrm{l}(n$ 2), 100$199 \mu \mathrm{g} / \mathrm{l}(n$ 5) and 200-299 $\mu \mathrm{g} / \mathrm{l}(n$ 1) and no participant was on anti-thyroid medication.

\section{lodine in urine and tap water}

The median UIC was $101 \mu \mathrm{g} / \mathrm{l}$ (interquartile range 69-153 $\mu \mathrm{g} / \mathrm{l}$; range $21-1870 \mu \mathrm{g} / \mathrm{l})$. A total of $37 \%$ of urine samples were in the range of adequate status (UIC 100-199 $\mu \mathrm{g} / \mathrm{l}$ ). None of the samples from participants had UIC in the range of severe iodine deficiency (UIC $<20 \mu \mathrm{g} / \mathrm{l}$ ), whereas $10 \%$ were in the range of moderate deficiency (UIC 20-49 $\mu \mathrm{g} / \mathrm{l}$ ), 39\% mildly deficient (UIC 50-99 $\mu \mathrm{g} / \mathrm{l}$ ), $9 \%$ were just above the recommended range (UIC 200-299 $\mu \mathrm{g} / \mathrm{l}$ ) and $6 \%$ of the samples had UIC above $300 \mu \mathrm{g} / \mathrm{l}$ (Fig. 1). Significantly more women than men had below the median value $\mathrm{UIC}<101 \mu \mathrm{g} / 1(61.9 \% v .41 .5 \%, P<0.001)$. Conversely, a total of $8.2 \%$ of the samples from men and $2.0 \%$ of the samples from women had UIC $>300 \mu \mathrm{l}$.

Tap water iodine was low ( $<2 \cdot 0 \mu \mathrm{g} / \mathrm{l})$ on all locations (Fig. 2).

\section{Determinants of iodine nutrition}

The demographic and lifestyle characteristics presented in Table 1 do not explain any pattern regarding the UIC level except for sex, as women have significantly lower levels compared with men $(P<0 \cdot 001)$. Although not significantly so, it seems as BMI is positively associated with UIC and the opposite direction is observed for educational attainment (see Table 1).

Intake of fish, whale meat and whale blubber was significantly associated with UIC, as the group with an intake in the fourth quartile of the respective food items had significantly higher UIC compared with low intake (see Table 2). We did not detect any association between the intake of whole grain and UIC.

Men were more than twice as likely to have UIC above the median concentration compared with women in the binary logistic regression $(\mathrm{OR}=2.30, \quad P<0.001)$; overweight $(25 \cdot 0 \leq \mathrm{BMI}<30 \cdot 0)$ and obese participants $(\mathrm{BMI} \geq 30 \cdot 0)$ were likely to have above median iodine status, although not significantly so $(\mathrm{OR}=1.23, P=0.047$ and $\mathrm{OR}=1.67, P=0.07)$ compared with normal-weight participants. For educational attainment, participants with upper secondary school were close to half as likely to have sufficient iodine status compared with those with 7 years of schooling $(\mathrm{OR}=0.53, \quad P=0.01)$. Regarding dietary intake, fish, whale meat and whale blubber were positively associated with iodine status (respectively: $\mathrm{OR}=1.79, P=0.06 ; \mathrm{OR}=1.43, P=0.22 ; \mathrm{OR}=1.88, P=0.02)$. There was no association between iodine status and age 


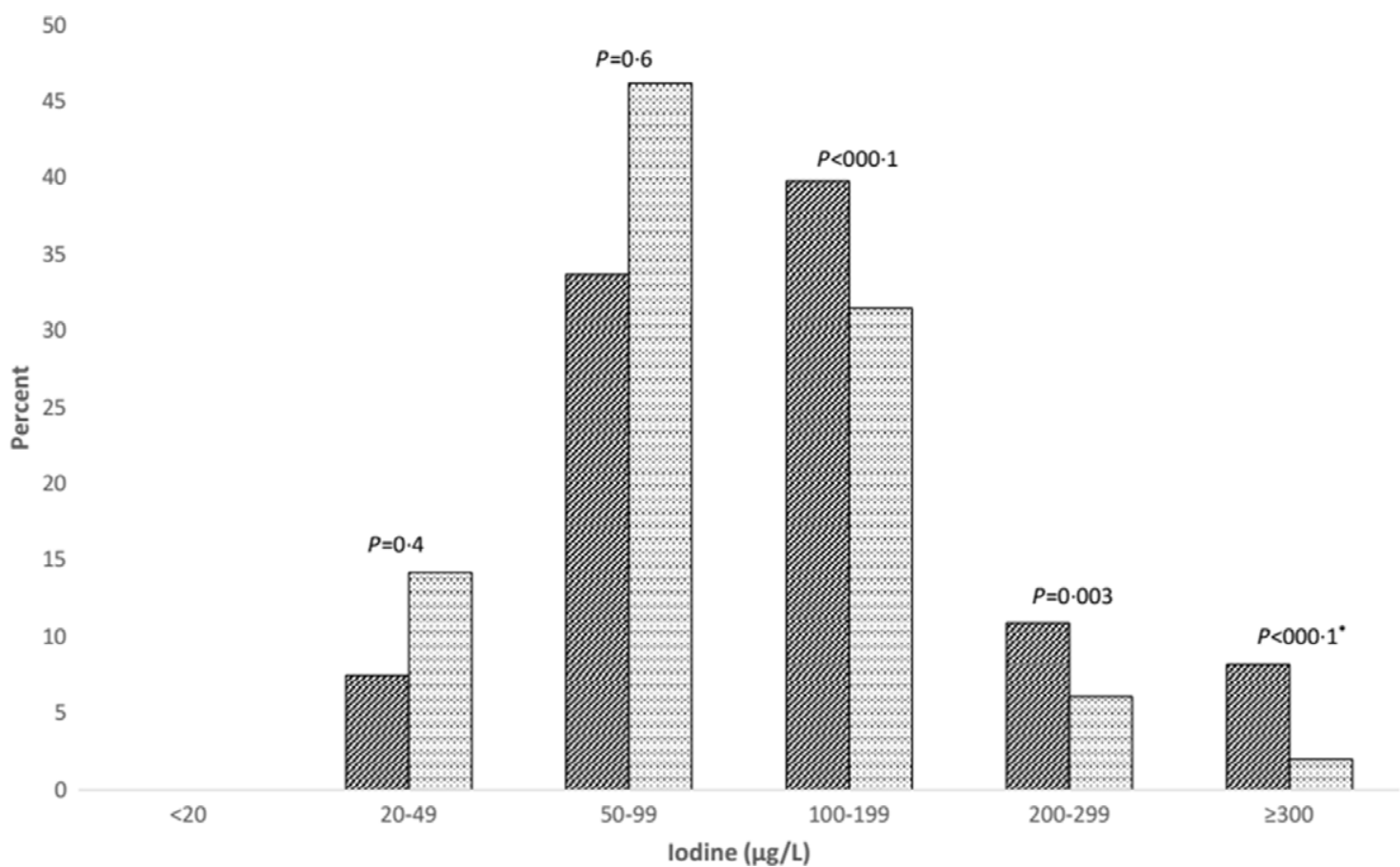

Fig. 1. Proportions of urinary iodine concentrations among a population-based sample of 491 adult Faroese men and women divided into the following groups: moderate, mild deficiency, adequate, slightly increased and excess. $P$-values assemble sex differences assessed by one-sample $\chi^{2}$. ${ }^{*} 4$ in the female group. $\square$, Male; $₫$, Female

(OR $=0.99, P=0.58)$; place of living $(\mathrm{OR}=1.002, P=0.9)$; smoking status (corresponding to daily: smoking occasionally, $\mathrm{OR}=2 \cdot 11, P=0 \cdot 17$ and never smoking, $\mathrm{OR}=1 \cdot 17, P=0 \cdot 45)$ and whole grain intake (OR $=1 \cdot 07, P=0 \cdot 80)$. Sex, BMI status, educational level and seafood intake (fish, whale meat and whale blubber) were included in the multivariable logistic regression model, and positive predictors retained were sex (male) $(\mathrm{OR}=3.29, P=0.03)$ and whale meat (fourth quartile) $(\mathrm{OR}=2 \cdot 94, P=0 \cdot 06)$.

\section{Discussion}

Main finding

Our study provides the first data to describe iodine nutrition status in the population in the Faroe Islands. Median UIC was $101 \mu \mathrm{g} / \mathrm{l}$, which is by WHO considered to be within the recommended range. A total of $37 \%$ of urine samples were in the iodine replete range of $100-200 \mu \mathrm{g} / \mathrm{l}$, whereas $39 \%$ were in the range of mild iodine deficiency $(100>\mathrm{UIC}>50 \mu \mathrm{g} / \mathrm{l})$ and $10.2 \%$ of samples were in the range of moderate iodine deficiency $(50>\mathrm{UIC}>20 \mu \mathrm{g} / \mathrm{l})$. This fraction complied with the goal of no more than $20 \%$ of the population samples lower than $50 \mu \mathrm{g} / \mathrm{l}$ and a median UIC above $100 \mu \mathrm{g} / \mathrm{l}^{(6)}$. Importantly, none of the participants' samples had UIC in the range of severe iodine deficiency. Overall, women had lower UIC and compared with men with nearly half of samples suggesting mild to moderate iodine deficiency. Conversely, more than twice as many men had concentrations above the recommended range (UIC $\geq 200 \mu \mathrm{g} / \mathrm{l}$ ), and for susceptible groups, this might pose a risk of iodine-induced thyroid dysfunction ${ }^{(1,31)}$.

\section{Comparison with other studies}

In Denmark, results from the DanThyr follow-up study conducted in 1997-1998 and again in 2008-2010 including 2465 participants (women aged 18-65 and men aged 60-65 years) reported an increase in median UIC from 61 to $83 \mu \mathrm{g} / \mathrm{l}$. The increased iodine level was mainly ascribed to the iodine supplementation programme introduced in 1998. It included mandatory iodine fortification of table salt and fortified salt as a compulsory ingredient in commercial bread production from year $2000^{(32)}$. The approach was a cautious introduction of iodine supplementation ${ }^{(10)}$, and the median UIC in the general population is still below the recommended level, corresponding to mild or borderline iodine deficiency ${ }^{(33)}$. In a convenience sample in Norway $^{(34)}$ of 276 participants aged 3+ years, the median UIC was $101 \mu \mathrm{g} / \mathrm{l}$ for the whole group, but for adults aged 18-64 years and elderly aged $65+$ years, the median concentrations were 96 and $62 \mu \mathrm{g} / \mathrm{l}$, respectively, suggesting inadequate iodine intake and a need for monitoring of iodine intake. In Sweden at the beginning of the twentieth century, the occurrence of goitre was about $18 \%{ }^{(35)}$; therefore, the Swedish national iodine fortification programme for table salt started in 1936. Results from a representative national Swedish sample ( $n$ 889) of children aged 6-12 years included median UIC of $125 \mu \mathrm{g} / 1$ and thus stated a sufficient iodine status ${ }^{(36)}$. A newly published review on iodine status in twenty-three European countries was based on forty studies with a total of 63000 individuals covering schoolchildren, pregnant women and adults. This review concluded that iodine deficiency is a continuous concern in Europe, especially among adults and pregnant women, and that monitoring is needed ${ }^{(37)}$. Our study on iodine 


\section{FAROE ISLANDS}

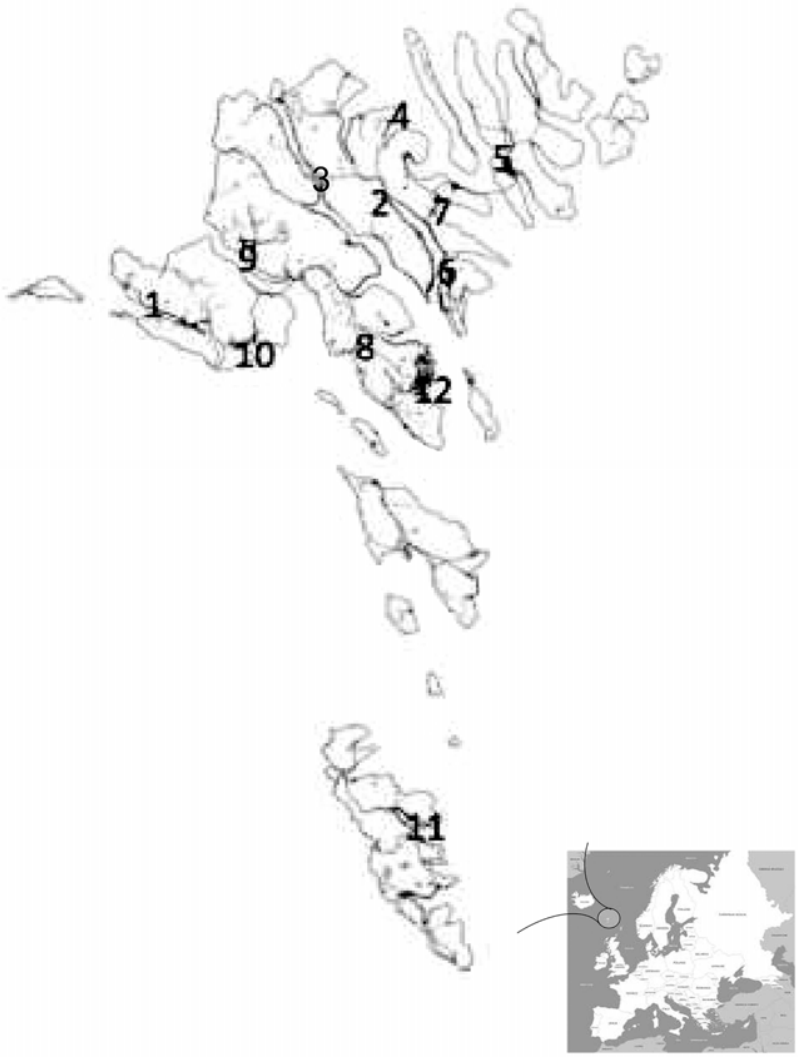

Fig. 2. Map showing the twelve locations for tap water collection in the Faroe Island. All samples had values $<2 \mu \mathrm{g} / \mathrm{ll}$. (1) Sørvágur, (2) Skálabotnur, (3) Við Streymin, (4) Fuglafjørður, (5) Klaksvík, (6) Runavík, (7) Gøta, (8) Kollafjørður, (9) Vestmanna, (10) Miðvágur, (11) Tvøroyri and (12) Tórshavn.

nutrition among Faroese aims to accommodate such recommendations to ensure good iodine health.

The sex-specific iodine intake found in our study with median UIC of $115 \mu \mathrm{g} / \mathrm{l}$ in males and $86 \mu \mathrm{g} / \mathrm{l}$ in females can partly be attributed to men's higher whale meat intake (data not shown). Thus, markedly more men than women were iodine replete with the higher levels in the male group being comparable with findings in other European countries ${ }^{(37)}$. Importantly, the lower level in women with a higher fraction being iodine deficient may be a concern with pregnancy raising the iodine need in women only ${ }^{(13)}$.

\section{Food sources}

The importance of fish as a source of iodine nutrient was mentioned as early as 1937 in a Faroese daily newspaper ${ }^{(38)}$, but no further iodine investigations were undertaken. Foods of marine origin have higher iodine content because marine plants and animals concentrate iodine from seawater, as seaweed is one of the best iodine food sources. Other good sources include fish and other seafood, as well as eggs and bread ${ }^{(39,40)}$. From early on, the major iodine source in the Faroe Islands is assumed to have been marine products and the population has been guessed to
Table 1. lodine urinary concentrations $(\mu \mathrm{g} / \mathrm{l})$ according to sex and age, demographic and lifestyle characteristics (Numbers; median and interquartile range (IQR))

\begin{tabular}{|c|c|c|c|c|}
\hline & \multicolumn{4}{|c|}{ Total study population } \\
\hline & $n$ & Median & IQR & $P^{*}$ \\
\hline Overall & 491 & 101 & $69-153$ & \\
\hline \multicolumn{5}{|l|}{ Sex } \\
\hline Male & 294 & 115 & $76-168$ & \multirow[t]{2}{*}{$<0.001$} \\
\hline Female & 197 & 86 & $61-131$ & \\
\hline \multicolumn{5}{|l|}{ Age groups (years) } \\
\hline $40-49$ & 89 & 122 & $76-161$ & \multirow[t]{4}{*}{0.17} \\
\hline $50-59$ & 124 & 100 & $70-139$ & \\
\hline $60-69$ & 201 & 96 & $64-149$ & \\
\hline 70-74 & 77 & 111 & $72-163$ & \\
\hline \multicolumn{5}{|l|}{ Location } \\
\hline City & 185 & 102 & $65-153$ & \multirow[t]{2}{*}{0.99} \\
\hline Village $<6000$ & 306 & 101 & $71-149$ & \\
\hline \multicolumn{5}{|l|}{ BMI† $\left(\mathrm{kg} / \mathrm{m}^{2}\right)$} \\
\hline$<24.9$ & 68 & 94 & $60-153$ & \multirow[t]{3}{*}{$0 \cdot 12$} \\
\hline BMI 25-29.9 & 218 & 98 & $67-146$ & \\
\hline $\mathrm{BMI}>30$ & 204 & 108 & $75-156$ & \\
\hline \multicolumn{5}{|l|}{ Smoking } \\
\hline Daily & 16 & 99 & $68-160$ & \multirow[t]{3}{*}{0.14} \\
\hline Occasionally & 17 & 136 & $85-248$ & \\
\hline Never & 335 & 102 & $69-145$ & \\
\hline \multicolumn{5}{|l|}{ Education $\ddagger$} \\
\hline 7 years & 211 & 106 & $75-158$ & \multirow[t]{3}{*}{0.22} \\
\hline $8-11$ years & 178 & 102 & $67-158$ & \\
\hline Upper secondary & 88 & 90 & $69-137$ & \\
\hline
\end{tabular}

* $P$-values were assessed by using non-parametric test Mann-Whitney $U$ test. † BMl information missing 1 for one study participant.

$\ddagger$ Education level missing for 14 study participants.

Table 2 lodine urinary concentrations $(\mu \mathrm{g} / \mathrm{l})$ for first and fourth quartile of three local traditional food items (Numbers; median and interquartile range)

\begin{tabular}{|c|c|c|c|c|c|}
\hline \multirow[t]{2}{*}{ Food item } & \multirow{2}{*}{$\frac{\text { Intake }}{\text { 1st v. 4th quartile }}$} & \multicolumn{4}{|c|}{ Total study population } \\
\hline & & $n$ & Median & IQR & $P^{\star}$ \\
\hline \multirow[t]{2}{*}{ Fish } & $1.5 /$ week or less & 121 & 94 & $61-139$ & 0.007 \\
\hline & 3/week or more & 67 & 110 & $77-183$ & \\
\hline \multirow[t]{2}{*}{ Whale meat $†$} & 2/year or less & 148 & 96 & $61-140$ & 0.04 \\
\hline & $14 /$ year or more & 73 & 111 & $73-172$ & \\
\hline \multirow[t]{2}{*}{ Whale blubbert } & $2 /$ year or less & 119 & 90 & $58-143$ & 0.004 \\
\hline & $20 /$ year or more & 118 & 112 & $79-168$ & \\
\hline \multirow[t]{2}{*}{ Whole grain } & Less than every day & 295 & 102 & $70-162$ & 0.90 \\
\hline & Once a day or more & 186 & 100 & $67-143$ & \\
\hline
\end{tabular}

* Mann-Whitney $U$ test between first and fourth quartile for each food item. † Globicephala melas.

be iodine replete due to the high frequency of seafood consumption $^{(41)}$. A dietary survey from 1982 including adult men and women found a daily fish intake of $78 \mathrm{~g}$ and a daily mean intake of iodine of $244 \mu \mathrm{g}\left(-24 \mu \mathrm{g}\right.$ females; $+32 \mu \mathrm{g}$ males $(n \text { 331) })^{(42)}$. Almost 20 years later, in 2001, a dietary investigation among pregnant women found that the daily fish intake had come down as low as $40 \mathrm{~g}^{(43)}$, corresponding to less than two meals per week. Recent data on fish intake recorded at the Department of Occupational Medicine and Public Health in the Faroe Islands indicate that the fish consumption may be even lower today $^{(24)}$, especially among the generation below the age of 30 years that includes the majority of pregnant women. Iodine concentration in Faroese cod is $15 \mu \mathrm{g} / \mathrm{kg}$ compared with 
$17 \mu \mathrm{g} / \mathrm{kg}$ in Denmark and $20 \mu \mathrm{g} / \mathrm{kg}$ in Iceland $^{(44)}$. The iodine content in fish seems low, and with the decreasing intake, we may assume that fish is not a main iodine source today. We did not detect any correlation between fish and whale meat intake but a weak positive overall association between fish and whale blubber intake. The logistic regression only retained whale meat as a positive predictor to the UIC. To our knowledge, there is no information available on the iodine content in pilot whale meat and blubber. But, a study conducted in Greenland reported the iodine content of whale meat to be $21 \mu \mathrm{g} / \mathrm{kg}$ and whale blubber $130 \mu \mathrm{g} / \mathrm{kg}^{(45)}$. The study does not state what type of whale but concludes that sea food in general has higher iodine contents compared with terrestrial animals.

Iodine content of tap water collected at twelve locations covering the geography of the Faroe Islands found a very low iodine content. Thus, iodine in drinking water does not contribute to iodine intake in the Faroe Islands in contrast to findings in example Denmark ${ }^{(28)}$ but comparable with findings in Greenland ${ }^{(16,45)}$. Other sources of iodine for the Faroese population include fortified salt available in grocery stores and used partly in commercial bread production. This may have compensated some of the reduction of intake of iodine-rich food items among the population of the Faroe Islands.

In regard to the dietary issues, the Faroese health authorities follow the Danish health authorities in terms of dietary recommendations. The Danish dietary recommendation, to the general public, of improving iodine intake is to increase the consumption of fish and whole grain as well as intake of lean dairy products. This could be done within the existing recommendation of healthy habits and by advising a dietary contributing $350 \mathrm{~g}$ of fish per week, of which preferably $200 \mathrm{~g}$ of fatty fish $^{(46)}$. Additionally, the Faroese health authorities recommend people to abstain from whale meat and blubber due to environmental contamination ${ }^{(22)}$

\section{Strengths and limitations}

This study has some limitations. The urinary samples are approximately 10 years old and were originally donated for a study concerning diet, contaminants and type 2 diabetes. The present study represents a secondary analysis of these data. The iodine status was similar across the original groups being at 'low risk', 'having prediabetes' and 'diabetes' and between the variables of age and BMI in the original group and in this present study is very similar with $R^{2}=0.024$ in the former and $R^{2}=0.008$ in the latter. The similarity across participant groups in the primary study supports the reliability of our findings.

Urine iodine concentrations vary markedly with both shortterm variations related to dietary peculiarities ${ }^{(47)}$ and long-term variation, and we do not have dietary information for the day of the urine sample. Diurnal variation in urinary iodine has been reported with lower concentration in morning urine and a $24 \mathrm{~h}$ sampling giving a better excretion estimate and thus thereby suggest a slight underestimation of our results ${ }^{(48)}$. However, with the sample size of 491 participants, we were able to determine the median UIC with $5 \%$ precision, as the required minimum of 489 samples was accommodated in accordance with recommendations for number of urine samples. Moreover, the sample size allowed for confidence when evaluating subgroups ${ }^{(30)}$. Furthermore, the study population reflects the general Faroese population in the respective age group 40-74 years, with the sex and age-adjusted sampling ${ }^{(25)}$.

The questionnaire was made to investigate the association between environmental contamination and risk of diabetes mellitus type 2 and therefore limited to food that might contain contamination, thus not containing iodine-specific questions, but $67 \%$ of the study population reported to eat whole grain daily to several times per day. The dietary information was based on reporting of food frequency without information on portion size and therefore carries some imprecision in reflecting the iodine intake, and we have no information about dairy intake nor on the intake of iodine containing supplements.

It is important to consider not only that the median iodine intake is sufficient but also to consider the total iodine exposition in the population. Pregnant and lactating women have greater need of iodine, and the recommended intake is $175-250 \mu \mathrm{g} / \mathrm{d}$ to target a median UIC of $150-249 \mu \mathrm{g} / 1$ during pregnancy and $>100 \mu \mathrm{g} / \mathrm{l}$ during lactation ${ }^{(40,49)}$. Our results indicate an increased risk of insufficient iodine intake among women of child-bearing age, pregnant and lactating women in the Faroe Islands, in keeping with indications that the younger generations consume less sea food and dairy products ${ }^{(15,36)}$.

\section{Concluding remarks}

This study among 40-74 years old randomly selected participants suggests that the iodine intake in The Faroe Islands overall is adequate. Some groups may still be iodine deficient though none was severely iodine deficient with UIC below $20 \mu \mathrm{g} / \mathrm{l}$. Samples from $48 \%$ of the population surveyed were in the range of insufficiency. Importantly, we found the lowest iodine excretion and thus the highest risk of iodine deficiency in Faroese women, which calls for studies on vulnerable groups.

\section{Future perspective}

Iodine intake in the Faroe Islands might be a cause of concern, and further studies are needed to substantiate the results and to examine the iodine status in younger generations, including young women likely to have a lower intake of iodine-rich food items. Pregnant and lactating women are a key focus as the developing brain is particularly vulnerable to the negative effects of iodine deficiency. The systematic monitoring of iodine status in different groups is important to follow trends in iodine nutrition. This is an important task for the health authorities, and there is a need for public health strategies to monitor and secure adequate iodine status, especially in young women and during pregnancy.

Furthermore, a randomised controlled trial in a population with mild iodine deficiency is warranted to provide authorities with guidance on recommendations for iodine supplementation during pregnancy. 


\section{Acknowledgements}

This study is in collaboration with The Thyroid Society Faroe Islands. Special thanks to Marita Hansen for helping and organisation.

This work was supported by the Research Council Faroe Islands (The Thyroid Society Faroe Islands and H. L. J. grant number 3118), The Research Council at the Faroese National hospital (H. L. J. grant number 18/00133-19) and Aalborg Hospital (S. A. grant number 3118) Dancea research programme, The Danish Environmental Protection Agency, grant number 112-00292.

The authors contributions were as follows: H. L. J. and P. W. were involved in conception of the study, H. L. J., S. A., P. W. and The Thyroid Society Faroe Islands were grant holders, H. L. J., G. S. K., A. S. V., P. W. and S. A. contributed to design and implementation of the study and preparation of the manuscript. S. A. did the iodine analyses. H. L. J., G. S. K. and A. S. V. did the data analysis.

There are no conflicts of interest.

\section{References}

1. Laurberg P, Cerqueira C, Ovesen L, et al. (2010) Iodine intake as a determinant of thyroid disorders in populations. Best Pract Res Clin Endocrinol Metab 24, 13-27.

2. Taylor PN, Albrecht D, Scholz A, et al. (2018) Global epidemiology of hyperthyroidism and hypothyroidism. Nat Rev Endocrinol 14, 301-316.

3. Brent GA (2012) Mechanisms of thyroid hormone action. J Clin Invest 122, 3035-3043.

4. Cheng SY, Leonard JL \& Davis PJ (2010) Molecular aspects of thyroid hormone actions. Endocr Rev 31, 139-170.

5. Riis J, Pedersen KM, Danielsen MB, et al. (2020) Long-term iodine nutrition is associated with longevity in older adults: a 20 years' follow-up of the Randers-Skagen study. Br J Nutr 125, 260-265.

6. World Health Organization (2007) Assessment of iodine deficiency disorders and monitoring their elimination. A Guide for Program Managers. na WHO WD 105, 1-99. https://apps. who.int/iris/bitstream/handle/10665/43781/9789241595827_ eng.pdf?sequence $=1$ \&isAllowed $=y$ (accessed March 2021).

7. Delange F (2001) Iodine deficiency as a cause of brain damage. Editorial Postgrad Med J 77, 217-220.

8. World Health Organization (2004) Iodine status worldwide WHO Global Database on Iodine Deficiency. WHO WD 105. Geneva: WHO. https://apps.who.int/iris/bitstream/handle/ 10665/43010/9241592001.pdf?sequence=1 (accessed March 2021).

9. Fødevareministeriets bekendtgørelse (Ministry of Food, Agriculture and Fisheries) (2000) Bekendtgørelse om tilsætning af jod til husholdningssalt og salt i brød og almindeligt bagværk m.v. (Order on the addition of iodine to household salt and salt in bread and ordinary baked goods, etc.). No. 627 of 29. June 2000. https://www.retsinformation. $\mathrm{dk} / \mathrm{eli} / \mathrm{lta} / 2000 / 627 \#:^{\sim}:$ text=Denne\%20bekendtg\%C3\%B8 relse\%20vedr\%C3\%B8rer\%20tils\%C3\%A6tning\%20af,tilsat \%20jod\%20indg\%C3\%A5r\%20som\%20ingrediens (accessed March 2021).

10. Laurberg P, Jørgensen T, Perrild H, et al. (2006) The Danish investigation on iodine intake and thyroid disease, DanThyr: status and perspectives. Eur J Endocrinol 155, 219-228.
11. Petersen M, Knudsen N, Carlé M, et al. (2018) Thyrotoxicosis after iodine fortification. A 21-year Danish population-based study. Clin Endocrinol 89, 360-366.

12. Zimmermann $M \&$ Boelaert $K$ (2015) Iodine deficiency and thyroid disorders. Lancet Diab Endocrinol 3, 286-295.

13. Andersen SL \& Laurberg P (2016) Iodine supplementation in pregnancy and the dilemma of ambiguous recommendations. Eur Thyroid J 5, 35-43.

14. Andersen SL, Sørensen LK, Krejbjerg A, et al. (2013) Iodine deficiency in Danish pregnant women. Dan Med J 60, A4657.

15. Adalsteinsdottir S, Tryggvadottir EA, Hrolfsdottir L, et al. (2020) Insufficient iodine status in pregnant women as a consequence of dietary changes. Food Nutr Res 64, 1-14.

16. Andersen S, Hvingel B, Kleinschmidt K, et al. (2005) Changes in iodine excretion in 50-69-year-old denizens of an Arctic society in transition and iodine excretion as a biomarker of the frequency of consumption of traditional Inuit foods. Am J Clin Nutr 81, 656-663.

17. Weihe P, Bjerregaard P, Bonefeld-Jørgensen E, et al. (2016) Overview of ongoing cohort and dietary studies in the Arctic. Int J Circumpolar Health 13, 33803.

18. Andersen S \& Laurberg P (2009) The Nature of iodine in drinking water. In Comprehensive handbook of Iodine, pp. 125-134 [Preedy V, Burrow G, Watson R, editors]. Oxford Academic Press. Elsevier Inc.

19. Statistics Faroe Islands (2021) Population. https://hagstova. fo/en/population/population/population-0 (accessed January 2021)

20. Joensen JP (2015) Bót og biti: Matur og matarhald í Føroyum (Traditional Faroese Food Culture). Tórshavn: Fróðskapur, Faroese University Press.

21. Whaling (2021) Whales and whaling in the Faroe Islands. https://www.whaling.fo/en/ (accessed January 2021).

22. Weihe P \& Joensen HD (2013) Dietary recommendations regarding pilot whale meat and blubber in the Faroe Islands. Int J Circumpolar Health 71, 18594.

23. Heilsufrøðiliga Starvsstovan (Faroese Food and Veterinary Authority) (2011) Kosttilmæli um at eta grind (Dietary recommendation for consuming pilot whale). https://hfs.fo/ webcenter/ShowProperty?nodeId=\%2Fhfs2-cs\%2FHFS010909\% 2F\%2FidcPrimaryFile\&revision=latestreleased (accessed March 2021).

24. Wennberg M (2021) Dietary Transition. AMAP Assessment 2021: Human Health in the Arctic. Arctic Monitoring Assessment Programme. Troms $\varnothing$, Norway: AMAP. (In the Press).

25. Veyhe AS, Andreassen J, Halling J, et al. (2018) Prevalence of type 2 diabetes and prediabetes in the Faroe Islands. Diab Res Clin Pract 140, 162-173.

26. Keating FR \& Albert A (1949) The metabolism of iodine in man as disclosed with the use of radioiodine - proceedings of the 1949 Laurentian hormone conference. Rec Progr Horm Res $\mathbf{4}$, 429-481.

27. Wilson B \& van Zyl A (1967) The estimation of iodine in thyroidal amino acids by alkaline ashing. Southafr J Med Sci 32, 70-82.

28. Andersen S, Pedersen KM \& Iversen F (2008) Naturally occurring iodine in humic substances in drinking water in Denmark is bioavailable and determines population iodine intake. BrJNutr 99, 319-325.

29. Laurberg P (1987) Thyroxine and 3,5,3'-triiodothyronine content of thyroglobulin in thyroid needle aspirates in hyperthyroidism and hypothyroidism. J Clin Endocrinol Metab 64, 969-974. 
30. Andersen S, Karmisholt J, Pedersen KM, et al. (2008) Reliability of studies of iodine intake and recommendations for number of samples in groups and in individuals. Br J Nutr 99, 813-818.

31. Leung AM \& Braverman LE (2014) Consequences of excess iodine. Nat Rev Endodrinol 10, 136-142.

32. Rasmussen LB, Jørgensen T, Perrild H, et al. (2014) Mandatory iodine fortification of bread and salt increases iodine excretion in adults in Denmark: a 11-year follow-up study. Clin Nutr 33, 1033-1040.

33. Andersen SL, Sørensen LK, Krejbjerg A, et al. (2015) Iodine status in Danish pregnant and breastfeeding women including studies of some challenges in urinary iodine status evaluation. J Trace Elem Med Biol 31, 285-289.

34. Brantsæter AL, Knutsen HK, Johansen NC, et al. (2018) Inadequate iodine intake in population groups defined by age, life stage and vegetarian dietary practice in a Norwegian convenience sample. Nutrients 17, 230.

35. Greenwald I (1960) Notes on the history of goitre in Sweden. Med Hist 4, 218-227.

36. Nyström HF, Brantsæeter AL, Erlund I, et al. (2016) Iodine status in the Nordic countries - past and present. Food Nutr Res 8, 31969.

37. Ittermann T, Albrecht D \& Arohonka P (2020) Standardized map of iodine status in Europe. Thyroid 30, 1346-1354.

38. Dagblaðið (Newspaper) (1937) Fisk og fiskeprodukter som næringsmiddel (Fish and fish products as food and nutrients). Torshavn. No 87-89. https://epaper.infomedia.dk/wxe/ 19370805 ? $s=\& p=($ accessed January 2021$)$.

39. Zimmermann MB (2009) Iodine deficiency. Endocr Rev 30 376-408.

40. Nordic Nutritional Recommendations (2012) Integrating Nutrition and Physical Activity. Iodine, 5th ed. Copenhagen: Nordic Council of Ministers.

41. Steuerwald U, Weihe P, Jørgensen PJ, et al. (2000) Maternal seafood diet, methylmercury exposure, and neonatal neurologic function. J Periatr 136, 599-605.
42. Vestergaard T \& Zachariassen P (1985) Føðslukanning 1981-82 (Dietary Investigation). Fróðskaparrit (Annales Societatis Scientiarum Foroensis) 33, 5-18.

43. Veyhe AS (2006) Færøske kvinders kostvaner i tredje trimester (Dietary survey with pregnant women from the Faroe Islands during their third trimester). http://www.diva-portal.org/smash/ get/diva2:731184/FULLTEXT01.pdf (accessed January 2021).

44. Heilsufrøðiliga Starvsstovan (2004) (Faroese Food and Veterinary Authority) Innihaldsevni í føroyskum toski (An Index of Faroese cod). https://www.hfs.fo/webcenter/ ShowProperty?nodeId=\%2Fhfs2-cs\%2FHFS017908\%2F\%2Fidc PrimaryFile\&revision=latestreleased (accessed July 2021).

45. Andersen S, Hvingel B \& Laurberg P (2002) Iodine content of traditional Greenlandic food items and tap water in East and West Greenland. Int J Circumpolar Health 61, 332-340.

46. Alt om kost (All about foods) (2021) Spis mindre kød vælg bælgfrugter og fisk (Eat less meat - choose legumes and fish). Ministeriet for Fødevarer, Landbrug og Fiskeri, Fødevarestyrelsen (The Danish Veterinary and Food Administration). https:// altomkost.dk/raad-og-anbefalinger/de-officielle-kostraadgodt-for-sundhed-og-klima/spis-mindre-koed-vaelg-baelgfrugterog-fisk/ (accessed March 2021).

47. Noahsen P, Kleist I, Larsen HM, et al. (2019) Intake of seaweed as part of a single sushi meal, iodine excretion and thyroid function in euthyroid subjects: a randomized dinner study. J Endocrinol Invest 43, 431-443.

48. Andersen S, Waagepetersen R \& Laurberg P (2015) Misclassification of iodine intake level from morning spot urine samples with high iodine excretion among Inuit and non-Inuit in Greenland. Br J Nutr 14, 1433-1440.

49. Zimmermann MB (2007) The adverse effects of mild-tomoderate iodine deficiency during pregnancy and childhood: a review. Thyroid 17, 829-835. 